БАЛЫШЕВА О.Л., КЛУДЗИН В.В., КУЛАКОВ С.В., ШАКИН О.В.

\title{
АКУСТООПТИЧЕСКИЙ МЕТОД НЕРАЗРУШАЮЩЕГО КОНТРОЛЯ КАЧЕСТВА КРИСТАЛЛОВ ДЛЯ АКУСТОЭЛЕКТРОНИКИ
}

\author{
Санкт-Петербургский государственный университет аэрокосмического приборостроения, \\ Россия, Санкт-Петербург, 190000, ул. Большая Морская, 67
}

\begin{abstract}
Аннотация. Предложен акустооптический вариант реализации метода неразрушающего контроля качества кристаллов. Показаны возможности метода для исследования свойств кристаллов, применяемых в акустоэлектронных устройствах. Применен акустооптический метод «теневых» изображений. Визуализизация структуры акустических полей позволила оценить оптическую однородность материала и зафиксировать пространственные характеристики акустических волн, эффекты расходимости и отклонения направления распространения от волновой нормали
\end{abstract}

Ключевые слова: акустоэлектроника; акустооптика; акустооптический метод; неразрушающий контроль; кристалл; метод теневых изображений; акустическая волна

\section{ВВЕДЕНИЕ}

Акустоэлектроника и акустооптика являются активно развивающимися направлениями современной функциональной электроники. Являясь смежными областями, объединенными общими принципами функционирования и особенностями распространения акустических волн, они эффективно взаимодействуют, позволяя создавать гибридные устройства и использовать методы и подходы одного направления в решении практических задач другого.

В ходе разработки и практической реализации акустоэлектронных устройств одной из важнейших задач является исследование свойств материалов, используемых для подложек. В последние годы особое внимание уделяется поиску, синтезу и исследованию свойств группы кварцеподобных кристаллов $[1,2]$. Так, кристаллы лангасита $\left(\mathrm{La}_{3} \mathrm{Ga}_{5} \mathrm{SiO}_{14}\right)$ вытеснили в ряде применений традиционный кварц. Обладая лучшим набором материальных констант кристаллы семейства лангасита имеют большие перспективы применения в устройствах стабилизации частоты, термостабильных фильтрах и датчиках различных физических величин [3, 4].

Особенностью кристаллов лангасита и других кварцеподобных кристаллов служит сложный, по сравнению с кварцем, состав и не всегда упорядоченная кристаллическая структура. Для ряда соединений оказывается трудным подобрать условия роста кристаллов без видимых дефектов. Для всех кристаллов этой группы их свойства и параметры акустоэлектронных устройств на их основе зависят от состава и условий выращивания.

Известно, что состояние поверхности кристаллов, а также внутренние дефекты, неоднородности, примеси и дислокации, возникающие в процессе роста кристаллов, влияют на параметры распространяющихся акустических волн, ухудшая технические характери- 